\title{
Improved strength and durability of concrete by bacterial carbonate precipitation
}

\author{
Peihao Li ${ }^{1, a}$, Chongqi Liu ${ }^{1, b}$, Wei Zhou ${ }^{2, c}$ \\ ${ }^{1}$ College of Civil Engineering and Architecture, Zhejiang University of Technology, Hangzhou, China \\ ${ }^{2}$ School of Aerospace Engineering and Applied Mechanics, Tongji University, Shanghai, China

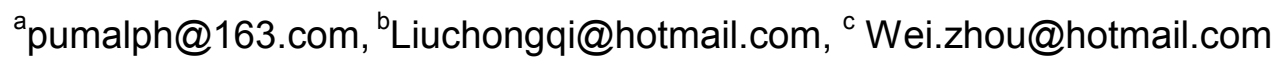

\begin{abstract}
Keywords: Bacterial carbonate precipitation, Concrete, Compressive strength, Durability, Water absorption

Abstract. Bacterial induced carbonate precipitation has led to the exploration of improvement technique about strength and durability of concrete. The aim of this study was to investigate the effects of bacterial carbonate precipitation on strength and the durability of concrete specimens. The influence of bacterial induced precipitation on concrete strength was studied through compressive strength test. Water absorption and the resistance towards carbonation of concrete were analyzed by water absorptivity test and concrete accelerated carbonation test, respectively. Experimental results show that bacterial induced carbonate precipitation is able to make the improvement in concrete compressive strength. Bacterial induced calcite precipitation on the surface of concrete specimens result in a decrease of capillary water uptake and carbonation rate constant, and an increase in resistance towards degradation processes.
\end{abstract}

\section{Introduction}

The porosity of concrete material along with ingress of detrimental components in moist environments, such as acids, chlorides, sulfates and so on, seriously reduce concrete material strength and concrete structure service life. Some measures were taken to diminish the uptake of water or to slow down or even to eliminate concrete degradation. Bacterial carbonate precipitation plays an important role in limiting the infiltration of detrimental components into concrete and lead to the exploration of technique in the field of concrete materials [1-2]. Various microorganisms have been used to increase the compressive strength of cement mortar and durability of concrete structures [3-4]. The application of bacterial carbonate precipitation to the field of concrete materials has been increasingly popular as its high potential technology. The most promising and feasible application is believed to enhance durability of concrete structures [5-6]. Bacterial carbonate precipitation on the surface of concrete specimens resulted in substantial decrease of water uptake and permeability compared to control specimens without bacteria.

The aim of this study was to investigate the effects of strain Acinetobacterjohnsonii induced carbonate precipitation on parameters affecting concrete properties and the influences of that on the durability of concrete specimens. Concrete strength was studied through compressive strength test. Durability was assessed from the permeation properties and resistance towards degradation processes. Water absorption and the resistance towards carbonation of concrete were analyzed by water absorptivity test and concrete accelerated carbonation test, respectively.

\section{Materials and methods}

Bacterial strain and culture media. The microorganism used throughout the study was Acinetobacterjohnsonii (The strain was isolated and purified from karst soil, and then through physiological and biochemical characteristics and based on the 16s rRNA sequence and the phylogenetic analysis, it was identified as Acinetobacterjohnsonii.). For inoculum preparation, Acinetobacterjohnsonii was precultured in liquid medium B4 $\left(\mathrm{Ca}\left(\mathrm{CH}_{3} \mathrm{COO}\right)_{2} 2.5 \mathrm{~g}\right.$; Yeast extract, $4.0 \mathrm{~g}$; Glucose 10.0g; agar 15.0g; $\mathrm{pH} \mathrm{8.0;} \mathrm{and} \mathrm{distilled} \mathrm{water,} 1 \mathrm{~L}$.$) . Individual ingredients were$ 
autoclaved separately and mixed afterward to avoid precipitation. Precipitation experiments were carried out in liquid medium (BT) containing the following $\mathrm{L}^{-1}$ of glass distilled water: $\mathrm{Ca}\left(\mathrm{CH}_{3} \mathrm{COO}\right)_{2}, 2.5 \mathrm{~g}$; Broth $3 \mathrm{~g}$; Yeast extract, $0.5 \mathrm{~g} ; 0.05 \mathrm{M}$ Tris buffer; distilled water, $1 \mathrm{~L}$; pH9.0. The $\mathrm{pH}$ of the medium was adjusted to 9.0 with $\mathrm{NaOH}$ prior to autoclaving for 20 min at $121^{\circ} \mathrm{C}$.

Concrete specimens and bacterial carbonate precipitation experiments. Concrete specimens were made by using ordinary Portland cement. The composition of the concrete mix: cement, $442 \mathrm{Kg}$; sand, $473 \mathrm{Kg}$; aggregates, $1280 \mathrm{Kg}$; and water, $221 \mathrm{Kg}$. Moulds with dimensions of $70 \mathrm{~mm}$ $\times 70 \mathrm{~mm} \times 70 \mathrm{~mm}$ and $40 \mathrm{~mm} \times 40 \mathrm{~mm} \times 160 \mathrm{~mm}$ were used. After casting, all moulds were placed in an air-conditioned room with a temperature of $20 \pm 2^{\circ} \mathrm{C}$ and a relative humidity of more than $90 \%$ for a period of $24 \mathrm{~h}$. After demoulding, the specimens were cured for more than 28 days. Some specimens with dimensions of $70 \mathrm{~mm} \times 70 \mathrm{~mm} \times 70 \mathrm{~mm}$ were used for compressive strength test, others with dimensions of $40 \mathrm{~mm} \times 40 \mathrm{~mm} \times 160 \mathrm{~mm}$ were used for capillary water absorption and accelerated carbonation test.

Bacterial carbonate precipitation experiments were conducted in liquid media. The culture was incubated on a shaker with constant shaking $160 \mathrm{rpm}$ for $24 \mathrm{~h}$ at $30^{\circ} \mathrm{C}$, which is the optimal duration for Acinetobacterjohnsonii to reach a density of $2.17 \times 10^{7} \mathrm{cfu} / \mathrm{mL}$ during the exponential growth. Cell concentrations were determined by viable cell counting on B4 plates. Specimens were placed in BT culture media and inoculated with Acinetobacterjohnsonii. A minimum of three specimens were run in each experiment.

Bacterial carbonate precipitation concrete specimens were immersed for $24 \mathrm{~h}(10 \pm 5 \mathrm{~mm}$ depth $)$ in a precultured $24 \mathrm{~h}$ old stock culture of Acinetobacterjohnsonii. After this inoculation, specimens were wiped with a paper towel to remove excess liquid. Following this wiping, specimens were immersed $(10 \pm 5 \mathrm{~mm}$ depth $)$ in precipitation medium. The specimens were removed from the medium in 3 days, 7days and 28 days, and left to dry for a week at room temperature. Control experiments identical to those indicated above were carried out without bacterial inoculation. The same procedure was used to check contamination of inoculated specimens.

Compressive strength test of concrete specimens, Acinetobacterjohnsonii was grown in B4 media. A cube mould of $70 \mathrm{~mm}$ was used,sand and cement were thoroughly mixed, adding along with grown culture of Acinetobacterjohnsonii correspondence to $4 \times 10^{7} \mathrm{cfu} / \mathrm{ml}$. Cubes were cast and compacted in a vibration machine. After de-molding, all specimens were cured in BT medium at room temperature until compression testing at the intervals of 3, 7 and 28 days. The concrete cubes were cured for 3, 7 and 28 days and tested for compressive strength. Control experiments were also prepared in a same way without adding bacterial cells.

SEM/XRD analysis. The morphology and mineralogical composition of the deposited carbonate crystals were investigated with scanning electron microscopy and X-ray diffraction. FESEM micrographs were obtained using FEI Sirion 200 apparatus. Specimens were gold coated with a JFC-1200 fine coater prior to examination. XRD-spectra were obtained using PANalytical B.V,X' PertPRO diffractometer with a $\mathrm{Cu}$ anode ( $40 \mathrm{kV}$ and $30 \mathrm{~mA})$.

Water absorption test. Absorptivity test was carried out to determine the increase in resistance towards water penetration. Concrete specimens were primarily coated at 4 sides adjacent to biodepostion treated side with polysiloxane and silicon paint. After coating, specimens were dried in an oven set at $105^{\circ} \mathrm{C}$ until a constant weight was reached.

The preconditioned specimens were exposed to $10 \pm 1 \mathrm{~mm}$ of water in an atmosphere of $20 \pm 2{ }^{\circ} \mathrm{C}$ and R.H. of $60 \pm 10 \%$, with the treated side facing downwards and water level about $2 \mathrm{~mm}$ above the base of the specimen. The water level was kept constant through addition of tap water. The sorptivity coefficient, $\mathrm{k}\left[\mathrm{cm} \mathrm{s}^{-1 / 2}\right]$, was obtained by using the following expression: $\frac{Q}{A}=K \sqrt{t}$

Where $\mathrm{Q}$ is the amount of water absorbed $\left[\mathrm{cm}^{3}\right] ; \mathrm{A}$ is the cross section of the specimen that was in contact with water $\left[\mathrm{cm}^{2}\right]$; $\mathrm{t}$ is the time $[\mathrm{s}], \mathrm{Q} / \mathrm{A}$ was plotted against the square root of time, then $\mathrm{k}$ was calculated from the slope of the linear relation between the former. 
Accelerated carbonation test.The accelerated carbonation tests were conducted in a $\mathrm{CO}_{2}$-closet at a temperature of $20 \pm 5{ }^{\circ} \mathrm{C}$, a R.H. of $70 \pm 5 \%$ and a $\mathrm{CO}_{2}$ concentration of $20 \pm 3 \%$. After $14 \mathrm{~d}$ of carbonation, specimens were removed from the closet. A slice $(10 \mathrm{~mm})$ perpendicular to the treated surface was cut off and sprayed with phenolphthalein solution for the determination of the carbonation depth. The remaining specimens was coated and put back in the $\mathrm{CO}_{2}$-closet. Carbonation depth was determined after 28, 42 and 56 d. Resistance towards carbonation is expressed as the carbonation rate constant $(\mathrm{K})\left[\mathrm{mm} \mathrm{s}^{-1 / 2}\right]$. This parameter can be obtained as follows:

$$
\bar{x}_{t}=K \sqrt{t}
$$

Where $\bar{x}_{t}$ is the mean carbonation depth [mm] after a certain time [years].

\section{Results and discussion}

XRD/SEM analysis. For strian Acinetobacterjohnsonii and culture medium BT, bacterially induced carbonate precipitation crystals are calcite and vaterite. Calcite is the main phase in culture medium BT (see Fig. 1). Details of bacterially induced carbonate precipitation under FESEM are depicted in Fig. 2. The crystal deposition serves as a barrier prevent detrimental substances from entering concrete specimens, and thus improves its impermeability. Bacterially induced carbonate precipitation (a thin calcification layer) by Acinetobacterjohnsonii, which plays an important role in enhancing the durability of porous concrete materials or structures.

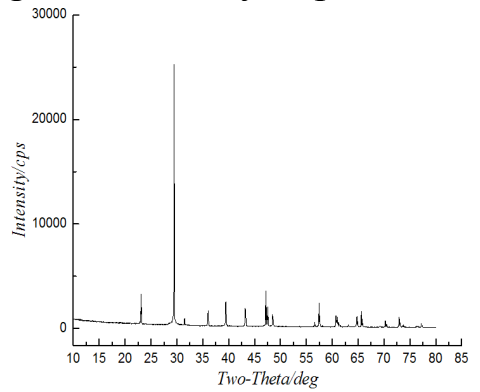

Fig.1. X-ray diffraction patterns of bacterially induced carbonate precipitation

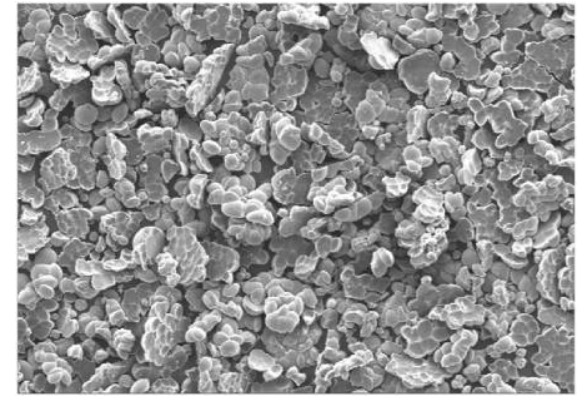

Fig.2. SEM micrographs of bacterially induced carbonate precipitation in M3 media

Compressive strength test. The concrete cubes were cured for 3, 7 and 28 days and tested for compressive strength. Compressive strengths of concrete cubes were tested to determine the efficiency of improvement by Acinetobacterjohnsonii induced precipitation. Fig. 3 shows the 3, 7 and 28 day compressive strength of concrete cubes containing Acinetobacterjohnsonii cells. The compressive strength had significantly increased for the concrete cubes that contained microbial cells. Concrete cubes containing bacterial cells showed about $21.1 \%$ improvement in compressive strength at 28 days compare with control specimen.

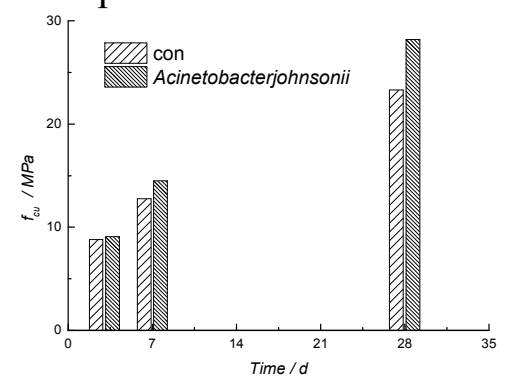

Fig.3. Compressive strength of concrete cubes by bacterial induced precipitation.

Water absorption and carbonation analysis. Fig. 4 shows the effects of bacterial induced carbonate precipitation on the water absorption for concrete specimens with different water-cement ratio, $W / C$. Concrete biotreatment specimens show significantly less water absorption compared to untreated specimens. The $W / C 0.7$ biodeposition treated specimens show a higher sorptivity coefficient than the $W / C 0.6$ and 0.5 biodeposition treated specimens. Due to the larger porosity and connectivity of the pores with increasing $W / C$, the absence of bacterial induced carbonate 
precipitation will have a larger effect on the water absorption of higher $W / C$ specimens than that of lower $W / C$ specimens. Fig. 5 shows the effects of boitreatment on the carbonation rate constants for concrete specimens with different $W / C$. The decrease in carbonation rate constants could be observed for the different $W / C$ specimens. The rate of carbonation of biotreatment was correlated to the water-cement ratio. The decrease in water absorption and carbonation rate constants results from the combined effect of the presence of biomass and carbonate deposition. In a word, biotreament effectively reduces capillary water uptake and leading to carbonation rate constant decrease by $66.3 \%$.

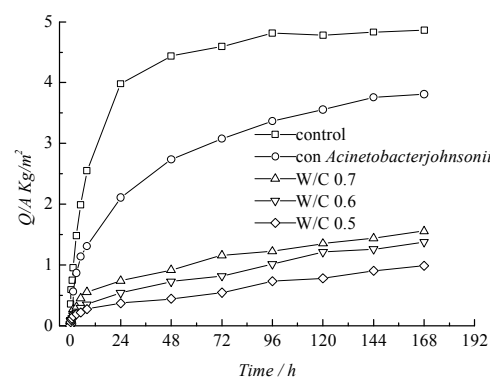

Fig. 4 The influence of bacterial induced carbonate precipitation on surface of concrete samples on the rate of water absorption.

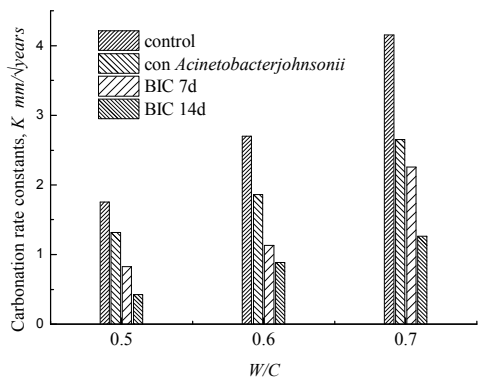

Fig. 5 Carbonation rate constants $K$ for different W/C concrete specimens applied with BIC

\section{Conclusions}

1. Concrete cubes by bacterially induced carbonate precipitation show about $21.1 \%$ improvement in compressive strength at 28 days compared to control specimen.

2. Bacterially induced carbonate precipitation (a thin calcification layer) by Acinetobacterjohnsonii, which results in an increased resistance of concrete specimens towards carbonation and water sorption, and effectively reduces capillary water uptake and leading to carbonation rate constant decreased by $66.3 \%$.

3. Bacterial induced carbonate precipitation is able to make the improvement in concrete compressive strength. Bacterial induced calcite precipitation on the surface of concrete specimens result in a decrease of capillary water uptake and carbonation rate constant, and an increase in resistance towards degradation processes.

\section{Acknowledgements}

This work was financially supported by Natural Science Foundation of China (No.51008281), the China postdoctoral science Foundation (No.2012M510119) and National Basic Research Program of China (No.2009CB623200).

\section{References}

[1] W.De Muynck, K. Cox, N. De Belie,et al: Constr. Build. Mater. Vol. 22 (2008), p.875-885.

[2] W. De Muynck, K.Cox, N. De Belie:Cem. Concr. Res. Vol. 38 (2008), p.1005-1014.

[3] N. Chahal, R. Siddique, A. Rajor:Constr. Build.Mater. Vol. 28 (2012), p. 351-356.

[4] R. Pei, J. Liu, S. Wan, et al:Cem.Concr. Comp. Vol. 39 (2013), p. 122-130.

[5] V. Achal1,A. Mukherjee, M. S. Reddy:J. Mater. Civ. Eng. Vol. 23 (2011), p.730-734.

[6] Kunal, R.Siddique, A. Rajor:Constr. Build. Mat. Vol. 52 (2014), p. 42-51. 